\title{
Protocol for a Systematic Review and Meta-analysis of Racial, Ethnic, and Socioeconomic Disparities in COVID-19
}

Keywords:

Posted Date: October 30th, 2020

DOI: https://doi.org/10.21203/rs.3.rs-35394/v2

License: (c) (1) This work is licensed under a Creative Commons Attribution 4.0 International License.

Read Full License 


\section{Abstract}

The authors have requested that this preprint be removed from Research Square. 